How to cite this document: Branco, P. (2009). S. Bernini (2007), Family Life and Individual Welfare in Post-war Europe: Britain and Italy Compared. Basingstoke: Palgrave Macmillan. £45.00, pp. 199, hbk. Journal of Social Policy, 38(1), 193-194. https://doi.org/10.1017/S0047279408002717

\title{
S. Bernini (2007), Family Life and IndividualWelfare in Post-war Europe: Britain and Italy Compared. Basingstoke: Palgrave Macmillan. $£ 45.00$, pp. 199, hbk.
}

The notion of a crisis within family life has in recent years gained increasing attention. Several authors have intensively debated all possible causes for such a crisis, taking into the public arena matters that, for many years, were seen as belonging to the private sphere. As Stefania Bernini rightly points out in her book, 'no other institution has proved as effective as the family as an instrument of political propaganda and as an amplifier of social concerns' (p. 131).

This so-called crisis is not however new. Bernini goes back to the years after the Second WorldWar - the book concentrates on the period between 1945 and the mid-1960s, but recente facts are also pointed out and evaluated in the light of what was happening in those years - providing a vivid picture of howfamilywas 'perceived, conceptualized and discussed'within the political, religious and professional discourses of the time. As the title suggests, the book focuses on comparing two countries, Britain and Italy, to explore how the discourses surrounding the 'family' have shaped welfare policy in both countries. In effect, Bernini highlights the recursive relationship between family and state, amutual influence which, as the author claims, "has been largely neglected in "classic" studies of the welfare state' (p. 3).

Throughout the book, Bernini involves the reader in themultitude of discourses that have been used to portray and represent the family in the post-war years. Drawing on a range of literature, Bernini makes a useful comparison between the British and the Italian contexts in which the 'family' - as the author recognises, a vague notion that we still use in the absence of a better term - has sought to play a political role as the first locus of citizenship. The family is suggested to play an important role in forming decent citizens e.g. normatively defining what a family is and what should be expected of it as well as socio-economically and culturally as the bastion of solidarity. All these roles played by the family, be it in Britain or in Italy, have important implications for the whole of the welfare policies towards family itself.

Strangely, both countries show similarities that one would not think existed. Chapter 1 gives the reader some general insights on the content and approaches informing the book, while within Chapters 2 and 3 - as I see it, themost interesting chapters in the book - the author deals head on with the conceptual issues that frame this discussion. For example, Bernini explores the political discourses of the party's in power - Christian Democrat and Communist in Italy, Conservative and Labour in Britain - the moral/religious influences - Catholic and Anglican Churches - and scientific standpoints - especially those offered by social workers, doctors and psychologists. He discusses how each sees the family as an essential and natural unit, prior to the state, 'based upon marriage and having the nurturing of children as its first aim' (p. 133). This, of course, had implications for the 
way that sexuality was constructed as well as the roles assigned to men and women both inside and outside the family. Actually, one of the most interesting points Bernini makes is the highlighting of the ambiguous fact that while the woman/mother, even if always dependent on the man/husband for financial resources, is seen as the centre of the family institution (one could say that all good and all evil things happening to the family and its members were her responsibility), while the man/father is overshadowed and solely regarded as the breadwinner, even if he is assigned the household's authority and legitimacy.

Other important issues tackled in the book are around the 'ideal' of family (i.e. the number of children and the nuclear v. enlarged family), divorce and the link between women's participation in the labour market and the decline in birth rates.

Chapters 4 and 5 focus on the development of social policies towards children, especially raising the questions of 'maladjustment', 'juvenile delinquency', 'problem families' and child neglect, and how those matters have been seen as centrally about the role played by families and the state in addressing these issues. For example, on the latter issues, it is interesting to note that almost 50 years on, the question of legitimate and illegitimate children is still a concern in Italy. Thus, while a vast majority of couples are deciding not to marry, marriage is still seen within social policy as fundamental so that children born outside marriage have the same rights as those born to married couples (Fabri, 2008).

At this point, the extent and outcome of the policy measures taken forward in both countries are evaluated and criticised by Bernini. In summary the author notes that diferences in the welfare state frameworks in the two countries are important to how family policy has evolved,with Britain'swelfare state historically having amore vigorous function in the provision of child assistance and the means of intervention in family life, while in Italy the state had a more limited role and the organisations in place had mainly a voluntary nature, often connected to the Catholic Church.

In the end, what Stefania Bernini provides, by comparing the cases of Britain and Italy, is awareness of the fact that 'the family', always portrayed as natural, is, in reality, a social construction. Its definitions/limits, especially its relevance in terms of policy measures and state interventions, are a sort of potpourri of different conceptions and different conditions, always a product of their own time. It is this that accounts for much of the state of family life in our times.

\section{Reference}

Fabbri, D. (2008), 'Naturale = Legittimo?', in La Repubblica delle Donne, Anno 13 , n. 610, 9 August 2008. Rome: Supplement to the newspaper La Repubblica.

Patrícia Branco

University of Coimbra 